\title{
PROPRIETARY RIGHTS AND COLLECTIVE ACTION: THE CASE OF BIOTECHNOLOGY RESEARCH WITH LOW COMMERCIAL VALUE
}

\author{
Arti K. Rai ${ }^{1}$
}

In areas of cumulative research such as biotechnology, broad patents on

fundamental research tools have the potential to create impediments to follow-on

research and development. ${ }^{2}$ Impediments to R\&D may also be created by a possible "anticommons" or "thicket" of upstream rights. ${ }^{3}$ Whether such impediments actually

arise in any given case is of course an empirical question. From an empirical standpoint, the net impact of recent increases in upstream biotechnology rights is far from clear. ${ }^{4}$ It is fair to say, however, that one standard market solution to rights fragmentation - the reduction of transaction costs through collective institutions that pool and exchange rights

\footnotetext{
1 Professor of Law, Duke University School of Law. I thank Yochai Benkler, Wes Cohen, and participants in the April 2003 Duke symposium on Global Public Goods for very helpful comments. Alan Bennett and Anthony So are also due thanks for providing valuable information. Any mistakes or omissions are mine alone.

2 See, e.g., Arti K. Rai, Fostering Cumulative Innovation in the Biopharmaceutical Industry: The Role of Patents and Antitrust, 16 BERKELEY TECH. L.J. 813 (2001); see also Robert P. Merges \& Richard R. Nelson, On the Complex Economics of Patent Scope, 90 CoLum.L.REv. 839 (1990) (discussing general problem of broad rights on pioneer inventions).

Michael Heller \& Rebecca Eisenberg, Can Patents Deter Innovation? The Anticommons in Biomedical Research, 280 SCIENCE 698 (1998). It is important to note that both problems (a broad patent as well as a proliferation of patents) can, and often do, arise simultaneously. See Merges \& Nelson at (describing situations involving one broad pioneer patent holder and one or more holders of narrower follow-on patents). This counter-intuitive result can occur because the patent system permits subsequent improvers to stake patent claims within the scope of an initial inventor's broad claim. Indeed, it is quite possible that anticommons-type problems are particularly difficult to address where the relative strength of the patents held by the relevant parties is not symmetric. I discuss this problem of an "asymmetric anticommons" infra ..

${ }_{4} \quad$ Compare Heller \& Eisenberg, supra note 2, and Arti K. Rai \& Rebecca S. Eisenberg, Bayh-Dole Reform and the Progress of Biomedicine, 66 LAW \& CONTEMPORARY PROBLEMS 289 (2003) (discussing possible problems for follow-on research) with John Walsh, Ashish Arora, \& Wesley Cohen, The Patenting and Licensing of Research Tools and Biomedical Innovation, in PATENTS IN THE KNOWLEDGE-BASED ECONOMY 285 (National Academies Press 2003) (finding that upstream rights do not generally stop product development but expressing caution about certain broad patents). See also Iain Cockburn, The Changing Structure of the Pharmaceutical Industry, 23 HEALTH AFFAIRS 10 (2004) (discussing advantanges and disadvantages of upstream rights)
} 
$-{ }_{-5}^{5}$ has not emerged. Rather, in the commercial arena, significant transaction costs and licensing fees have simply become part of the cost of doing business. Although these costs have probably reduced profits, foreseeable sales revenues have been sufficiently high that the profit incentive has not been eliminated. ${ }^{6}$

In contrast, when follow-on research is conducted in the university context, ${ }^{7}$ or by non-profit institutions that target the developing world, ${ }^{8}$ foreseeable payoffs are either highly uncertain or are clearly small. In these contexts, large transaction and licensing costs may pose a more pressing problem. On the other hand, at least in the context of low-margin research, there is reason to be optimistic that the "standard" solution of collective rights management may actually work. When the follow-on research in question is of demonstrably low commercial value, there is no reason for upstream rightsholders to fear that they are foregoing large downstream rents. Thus, even though conditions in the biotechnology sector may, as a general matter, work against collective action, low-margin research may be an exception. Non-profit institutions such as universities that are highly sensitive to reputational pressures, should be the easiest players to enlist. Fortunately, in both agricultural and health-related biotechnology, nonprofit institutions own a significant percentage of patents.

\footnotetext{
$5 \quad$ See, e.g., Robert Merges, Contracting Into Liability Rules: Intellectual Property Rights and Collective Rights Organizations, 84 CAL.L.REV. 1293 (1996).

6 The study by Walsh, Arora, and Cohen, which concluded that R\&D projects went forward despite significant increases in licensing and transaction costs, focused on the commercial sector. The authors conducted interviews with scientists, intellectual property managers, and business people from 25 different firms (10 pharmaceutical firms and 15 biotechnology firms). In contrast, they conducted interviews with personnel from only 6 universities. Walsh et al., supra note 3, at 293.

Rai \& Eisenberg, supra note 3 (identifying problems faced by academic researchers); Eric Campbell et al., Data Withholding in Academic Genetics: Data from a National Survey, 287 JAMA 473 (2002) (survey of academic geneticists). 8 See infra
} 
In fact, low-margin research is the area of biotechnology in which we have seen the most significant movement towards collective rights management. In the area of agricultural biotechnology research for developing countries, a 22-university consortium has been established to address impediments posed by upstream rights. Considerable efforts are also being made to achieve collective action in the areas of health-related biotechnology for developing countries. Moreover, although universities and other nonprofit institutions are probably the most likely candidates for successful collective action, there may be also some possibility of involving the private sector.

This essay proceeds in four parts. Part I gives a brief history of recent rights expansion and proliferation in upstream biotechnology. It argues that while large firms that conduct research in biopharmaceuticals or in agricultural biotechnology may be able to expend the considerable sums of money necessary to circumvent obstacles posed by proprietary rights, it would be irrational for researchers working on projects of uncertain or low commercial value to expend such resources. This Part also gives evidence of situations in which upstream complexity appears to have impeded research of uncertain or low commercial value. Part II discusses the likelihood of collective action, particularly public sector collective action, to reduce impediments to research of uncertain or low commercial value. It argues that collective action in the area of lowmargin research has significant prospects for success. Part III describes efforts by the public sector to secure collective rights management for humanitarian purposes in the area of agricultural biotechnology. It also examines the feasibility of similar efforts currently under way in the area of low-margin biomedical research. Part IV concludes by 
discussing the extent to which the private sector might need to be involved as well as other limitations of public sector collective action.

\section{The Impact of Upstream Proprietary Rights}

\section{A. Increases in Upstream Proprietary Rights}

In the area of biotechnology research, both biomedical and agricultural, the last two decades have been characterized by a significant increase in the number of upstream proprietary rights. ${ }^{9}$ In the biomedical area, the increase in upstream numbers is perhaps best demonstrated through the patent statistics of research universities. ${ }^{10}$ While U.S. universities received only 264 patents annually in 1979, that number had increased to 3,764 by $2000:{ }^{11}$ about half of recent university patents appear to be in the biomedical arena. $^{12}$ The number of plant biotechnology patents granted by the U.S. Patent and Trademark Office has also increased substantially in the past two decades. ${ }^{13}$

Additionally, according to patent mapping done by Geoffrey Graff and his colleagues, these patents appear to cover virtually all of the basic technologies necessary to conduct research in agricultural biotechnology. ${ }^{14}$

$9 \quad$ The number of proprietary rights in biotechnology as a whole has also increased. The Biotechnology Industry Organization reports that the number of biotechnology patents issued grew from 2000 in 1985 to over 13,000 in 2000. www.bio.org/er/statistics.asp

$10 \quad$ Universities tend to conduct a significant amount of basic biomedical research. In contrast, according to one study, only $14 \%$ of private sector pharmaceutical R\&D in the 1990s was devoted to basic research. TRENDS IN FEDERAL SuPPORT OF RESEARCH AND GRADUATE EDUCATION 80 (Stephen Merrill, ed., 2001).

11 Assocation of University Technology Managers, FY 2001 Survey Summary, available at $<<$ wwww.autm.net/indexie.html >> (visited June 28, 2004)

$12 \quad$ Arti K. Rai and Rebecca S. Eisenberg, Bayh-Dole Reform and the Progress of Biomedicine, 91 AMERICAN SCIENTIST 52, 54 (2003) (citing data from Bhaven N. Sampat, Georgia Institute of Technology). See also D.C. Mowery et al., The Growth of Patenting and Licensing by U.S. Universities: An Assessment of the Effects of the Bayh-Dole Act of 1980, 30 RESEARCH POLICY 99, 117 (2001) (noting that leading patents at the University of California, Stanford, and Colmbia "are concentrated in the biomedical arena.") $13 \quad$ Geoffrey D. Graff, Susan E. Cullen, Kent J. Bradford, David Zilberman, \& Alan B. Bennett, The Public-Private Structure of Intellectual Property Ownership in Agricultural Biotechnology, 21 NATURE BIOTECHNOLOGY 989, 990 (2003)

$14 \quad I d$. at 991-995 (discussing patents on range of enabling technologies and trait technologies). 
Whether claim scope has increased is less clear. Indeed, given the apparent hostility of at least some members of the Court of Appeals for the Federal Circuit to broad biotechnology patent claims, ${ }^{15}$ such claims may be suspect. Nonetheless, some patents with controversially broad claims have issued in recent years. For example, in June 2002, Harvard, MIT, and the Whitehead Institute received a patent on federallyfunded research involving the NF-kB cell signaling pathway. ${ }^{16}$ The patent claims all drugs that work by inhibiting the pathway. Because the NF-kB pathway is a fundamental pathway involved in diseases ranging from cancer and osteoporosis to atherosclerosis and rheumatoid arthritis, the patent may cover drug treatments for all of those diseases. Indeed, the exclusive licensee of the NF-kB patent, Ariad Pharmaceuticals, is suing, or threatening to sue, dozens of companies with drug products that inhibit the pathway. ${ }^{17}$ Another recent example of broad claiming is the University of Wisconsin's patent on primate embryonic stem cells. The 1998 patent claims all such stem cells, no matter how they are derived, even though, at the time of the patent application, researchers had succeeded in deriving the cells from rhesus monkeys and macaques only. ${ }^{18}$

Even when a research tool is not patented, universities and private firms may leverage their physical control over the tangible tool into a percentage of the profits from

\footnotetext{
15 See, e,g., Univ. of Rochester v. G.D. Searle \& Co., 358 F.3d 916 (Fed. Cir. 2004), reh'g denied, F.3d _ (2004); Enzo Biochem, Inc. v. Gen-Probe, Inc., 285 F.3d 1013 (Fed. Cir. 2002), on reh'g, 323 F.3d 956 (2002); Regents of the University of California v. Eli Lilly, 119 F.3d 1559 (Fed. Cir. 1997). However, because all of these opinions are authored by a single judge and have been controversial both within the Federal Circuit and in the larger patent community, their long term viability is not clear. $16 \quad$ Nuclear Factors Associated With Transcriptional Regulation, U.S Patent No. 6,410,516, issued June 25, 2002.

17 Sharon Begley \& Laura Johannes, Ariad Alleges Eli Lilly Drugs Infringe on Biomolecule Patent, WALL ST.J., June 28, 2002, at C1; see also www.ariad.com/about/about/nnfkb.html (last updated March 10, 2004)

18 James A. Thomson, Primate Embryonic Stem Cells, U.S. patent No. 5,843,780 (issued December 1, 1998). To be sure, broad claiming on fundamental research is not entirely a new phenomenon. The Cohen-Boyer patent applications, which were filed in the late 1970s, broadly claimed one of the fundamental techniques of modern molecular biology - transforming a bacterial host with foreign DNA. The Cohen-Boyer patent was, however, licensed nonexclusively at a reasonable royalty.
} 
subsequent commercial products. If the recipient of the tool is a commercial entity, the research tool owner may seek a reach-through royalty. If the tool recipient is a university, the research tool owner may seek a reach-through license to any subsequent intellectual property. An NIH working group study conducted in the late 1990s concluded that material transfer agreements ("MTAs") for the transfer of tools often contained reach-through terms. ${ }^{19}$

\section{B. Do Upstream Proprietary Rights Impede Follow-On Research?}

At least in theory, increased proprietary activity has the potential to impede subsequent research. Patent licensing entails not only supra-competitive pricing but also possible transaction cost problems associated with imperfect information, disparate assessments of value, and strategic behavior. Where a broad patent covers a research tool that would from, a social welfare standpoint, be best developed through widespread licensing, the combination of transaction costs and high licensing fees may impede this social desirable result. ${ }^{20}$ In the case of multiple upstream patents (whether broad or narrow), transaction costs and licensing fees associated with securing freedom to operate may be particularly problematic. ${ }^{21}$ A market optimist might counter such theorizing by noting that rights owners motivated to make a profit are likely to reduce transaction costs by forming patent pools that allow relatively free exchange of rights. With respect to licensing fees, rational, profit-maximizing rights owners are also likely to pricediscriminate in favor of resource-poor researchers.

\footnotetext{
19 See generally Report of the NIH Working Group on Research Tools, available at $<$ http://www.nih.gov/news/rsearchtools/index.htm>

$20 \quad$ Rai, Cumulative Innovation, at 833-34; Merges \& Nelson at _.

$21 \quad$ Heller \& Eisenberg, supra note 2.
} 
For better or for worse, the issue of actual impact is very difficult to resolve in theory. Unfortunately, empirical evidence on the actual impact of upstream biotechnology rights also fails to yield a definitive conclusion. But it does suggest that neither the market optimists nor the market pessimists are entirely correct. On the one hand, ongoing commercial projects do not appear to have been stopped by the inability to resolve concerns about upstream rights. On the other hand, there is some evidence of delayed, redirected, or even diminished research in areas where significant upstream proprietary positions exist. ${ }^{22}$ For present purposes, perhaps the most notable empirical result is the dog that did not bark: commercial patent pools and similar transaction costreducing institutions have not emerged. Rather, industry actors that produce end products, such as pharmaceutical companies, have put information in the public domain for the specific purpose of thwarting the proprietary designs of upstream firms. ${ }^{23}$ To some extent, firms have also avoided transaction costs by simply ignoring research tool patents and hoping that their infringement, even if detected, is detected after the six-year statute of limitations has run. ${ }^{24}$ Finally, and perhaps most commonly, downstream firms have simply endured licensing and transaction costs that run into the millions of dollars as a necessary evil. ${ }^{25}$

22 Walsh et al. at 317-20 (delayed researched); id. at 305 (redirected research); id. at 313 (diminished research in the area of patented targets).

${ }_{23} \quad$ See generally Robert Merges, A New Dynamism in the Public Domain, 71 U.CHI.L.REv. 183 (2004) (discussing "property-preempting initiatives" by pharmaceutical firms). One of these initiatives, the Single Nucleotide Polymorphism ("SNP") Consortium, an effort by pharmaceutical companies to put certain types of genomic information into the public domain, could be considered collective action of a sort. But efforts like the SNP Consortium, which aim to eliminate property rights, are quite different from property rights management. Downstream firms have also benefited from vigorous publicly funded efforts to undermine upstream rights. See Rai \& Eisenberg, supra note _, at 303-310 (discussing numerous activities undertaken by the National Institutes of Health in conjunction with academic scientists).

$24 \quad$ Walsh et al. at _.

25 Industry participants report that, for any given project, they normally have to consider a large number of patents, sometimes numbering in the hundreds. Although they can reduce this number to a more manageable size, such reduction typically occurs in several rounds and often takes many months. Walsh et 
In contrast, in university contexts, where the immediately foreseeable payoffs commercial or academic - from research is often not high, researchers are unlikely to be willing or able to incur high transaction costs in order to gain access to upstream research. Such costs appear to have been mounting, as academic researchers increasingly receive research tools under restrictive MTAs. According to the 1999 report of an NIH working group on research tools, even MTAs that merely transfer tools from one academic researcher to another can contain reach-through claims; requirements of publication delay pending a determination of intellectual property rights; and prohibitions on transfer of the tools to other research institutions. ${ }^{26}$

In a recent survey conducted by Eric Campbell and his colleagues, $47 \%$ of academic geneticists who had, within the previous three years, made requests for additional data or materials relating to research published by other academics reported that they were ultimately unable to secure access to such data or materials. ${ }^{27}$ This $47 \%$ figure represents a substantial increase over the $34 \%$ figure reported in a prior survey conducted by the same authors in the mid 1990s. To some extent, these denials had to do with factors unrelated to proprietary rights, such as scientific competition. ${ }^{28}$ However, the multivariate regression analysis performed by the authors of the survey indicated that denials were also independently associated with the need to honor the requirements of an industrial sponsor or the need to protect the commercial value of results. Moreover, the

al. at 319. After these transaction costs have been incurred, a number of patents have to be licensed. $I d$. at 295-96. In total, transaction and licensing costs can run into the millions of dollars. Id. at 318. Moreover, to the extent litigation is required, litigation costs often run into the millions of dollars.

26 See Report of the NIH Working Group on Research Tools, at 10 (available at http://www.nih.gov/news/researchtools/index.htm.

27 Eric G. Campbell et al., Data Withholding in Academic Genetics: Data from a National Survey, 287 JAMA 473 (2002).

$28 \quad I d$. at _. 
primary reason given by respondents who acknowledged denying requests for data or materials was the cost associated with such transfer. ${ }^{29}$ Although not limited to such costs, ${ }^{30}$ these costs likely include difficulties associated with complex negotiations over MTAs. Indeed, the survey authors specifically point to the complexity and restrictiveness of MTAs as creating impediments to sharing. ${ }^{31}$

As a consequence of these withholding behaviors, $28 \%$ of the respondents to the Campbell survey reported that they were unable to confirm the published results and $21 \%$ abandoned a promising line of research. One might reasonably hypothesize that the research in question that did not go forward because of access denials had uncertain commercial or academic payoff, as least as compared to ongoing industry research.

With respect to patented materials to which they do not need physical access, there is evidence that academics reduce licensing and transaction costs by simply ignoring the patents. ${ }^{32}$ Thus far, this "self-help" approach has enjoyed some success. Patentees have tended not to sue academics for their infringing uses, either because they are not aware of such uses or because (as market optimists might predict) refraining from such suits constitutes an informal regime of price discrimination in favor of cash-strapped researchers. This situation may be unstable, however. As universities are increasingly seen, particularly by the courts, as ordinary commercial players from whom damages can

\footnotetext{
$29 \quad$ Id. at

For some biomaterials, for example, the physical cost of transfer can be quite high. See, e.g., Share and Share Alike, 420 NATURE 602 (2002) (noting that the cost of duplicating the cDNAs described in scientist's paper was more than $\$ 10,000)$.

$31 \quad$ Campbell et al. at 479 (noting that "it may be that material transfer agreements have become so complex and so demanding that they inhibit sharing.")

$32 \quad$ Walsh et al. at
} 
be extracted ${ }^{33}$ barriers to suit may diminish. In the context of patented genetic diagnostic tests, for example, various industry players have already threatened to sue researchers, with the result, well-documented in empirical research by Jon Merz and Mildred Cho among others, that many academic diagnostic labs have stopped performing such testing. ${ }^{34}$ Although the issue of diagnostic testing is complicated by the reality that it constitutes both research and a commercial service provided to patients, the impasse in this area suggests that, in the future, price discrimination may not work as a mechanism for mediating the tension between the supra-competitive pricing allowed by proprietary rights and the limited budgets of most academic labs.

Similarly, in the context of research that is demonstrably of low commercial value, there is evidence that upstream proprietary rights have impeded downstream research. Consider the case of research into a malaria vaccine. The disease burden associated with malaria is very significant, on the order of over one million deaths a year. The social value of a malaria vaccine would therefore be quite high. Nonetheless, because the primary market for such a vaccine would be in the developing world, such research is of low commercial value. Moreover, the Malaria Vaccine Institute ("MVI"), the major philanthropic organization that is supporting research into a malaria vaccine, argues that upstream patent rights are an important factor in chilling vaccine R\&D. Specifically, according to a patent analysis commissioned by the MVI, the patent landscape surrounding just one antigen likely to be relevant to any vaccine that is

33 See Madey v. Duke University, _ F.3d _ (2002) (holding that there is no research exemption for universities, and emphasizing that universities nowadays engage in aggressive licensing and commercialization activities).

$34 \quad$ Jon Merz et al., Diagnostic Testing Fails the Test, 415 NATURe 577 (2002). 
ultimately developed is quite complex. As many as 34 different sets of patents describe and claim the antigen, MSP-1, or the production and delivery thereof. ${ }^{35}$

In the area of agricultural biotechnology, there is perhaps even more compelling evidence that research projects of low commercial value have been significantly delayed, or have not gone forward at all, because of upstream patent rights. Specifically, restricted access to patented technologies has been identified as a significant barrier to development of subsistence crops relevant to the developing world. ${ }^{36}$ A prominent example of upstream patent rights that have hindered creation of transgenic crops suited for subsistence farmers in developing countries are patents on two fundamental "enabling" technologies for inserting foreign genes into crops. The first of these patents issued to Cornell University in July 1990 and is licensed exclusively to Dupont. ${ }^{37}$ The second of these patents issued to Washington University in April 2000 and is licensed exclusively to Ciba-Geigy (now Syngenta). ${ }^{38}$ The private sector licensees of these patents have conducted -- and sublicensed others to conduct -- transgenic crop research relevant to the developed world. More generally, through a strategic combination of research, licensing, and merger activity, large agricultural biotechnology companies have assembled the intellectual property necessary to produce new crops of interest to the developed world. ${ }^{39}$ These companies have not, however, thus far shown interest in innovative research relevant to the developing world. The presence of proprietary rights

\footnotetext{
$35 \quad$ MVI Patent Analysis (on file with author).

Atkinson et al., supra note 14, at 174. G. Conway \& G. Toenniessen, 402 Nature C55 (1999).

General Biolistic-Mediated Transformation of Cells, U.S. Patent No. 4,945,050; see also Graff et al. at 992 (noting exclusive licensing to Dupont for most fields of use).

$38 \quad$ General Agrobacterium-Mediated Transformation of Dicots, U.S. Patent No. 6,051,757; see also Graff et al. at 992 (noting exclusive license to Syngenta).

$39 \quad$ Atkinson et al., supra note 14, at 174.
} 
has also hindered public sector efforts at humanitarian research. ${ }^{40}$ Similarly, private sector proprietary positions have hindered public sector efforts at conventional plant breeding directed to the needs of the developing world. ${ }^{41}$

In the context of research of uncertain or low commercial value, then, there is substantial reason to be concerned about upstream proprietary rights. One question that might reasonably be asked in these contexts, however, is whether collective action to reduce at least transaction costs - and perhaps even actual licensing costs - is likely to be more successful in the context of uncertain or low margin research than it has been in the context of high-margin research. The next Part considers the conditions under which we are most likely to see collective rights management that reduces licensing and transaction costs.

\section{The Prospect of Collective Action}

As institutional economists have frequently noted, securing collective action can be very difficult, particularly if the collective action requires sacrificing short-term gain. Success is most likely when the parties involved have shared values and interests; their numbers are relatively small; and they engage in repeated, readily observable interactions. $^{42}$ Given such preconditions, norms of behavior can develop and departures from these norms can be sanctioned through mechanisms such as shaming or exclusion. Absent such preconditions, there is a tendency to defect and attempt to maximize one's individual gain at the expense of the collective. Moreover, where the collective action

\footnotetext{
$40 \quad I d$. The presence of upstream patents has hindered not only low-value humanitarian R\&D but also R\&D in relatively low-value specialty crop areas, such as peanuts, broccoli, lettuce and tomatoes, in which the agribiotech industry does not have a strong commercial interest.

$41 \quad$ Jonathan Knight, A Dying Breed, 421 NATURE 568, 569 (2003).

42 See, e.g., ROBERT ElLICKSON, ORDER WiTHOUT LAW: How NEIGHBORS SETTLE DisPUTES 3 (1991); ELINOR OSTROM, GOVERNING THE COMMONS 88-89 (1990).
} 
involves pooling proprietary rights in some fashion, there generally needs to be some agreement on the value of the individual proprietary rights. ${ }^{43}$

The institutional economists' assumption that only relatively small, close-knit groups can produce successful collective action has recently been challenged by growth in open source software and other Internet-based cooperative projects. Participants in the development of open-source software are often relative strangers to each other. Nonetheless, they agree to work on software projects for which they will secure neither monetary reimbursement nor the usual sort of exclusive proprietary rights. ${ }^{44}$ More generally, the transaction-cost lowering effect of the Internet has allowed the emergence of a new production mode in which large numbers of relative strangers volunteer to work together on collective projects. ${ }^{45}$ Because the informational inputs of large numbers of individuals can be readily evaluated and integrated, reward mechanisms such as prestige or reputation that previously worked only in smaller groups can be extended more broadly. Such open source/commons-based production requires, however, not only low transaction costs but also low capital costs. In other words, volunteers must not be forced to invest resources other than time. In the area of "wet lab" biotechnology research, by contrast, large capital cost investments are still necessary. ${ }^{46}$

$43 \quad$ See Robert Merges, Contracting Into Liability Rules: Intellectual Property Rights and Collective Rights Organizations, 84 CAL.L.REV. 1293, 1345, 1353 (1996) (noting this point in the context of both informal and formal patent pools).

44 Depending on the type of open-source software development involved, the participants may either renounce intellectual property rights in their software contributions or they may retain such rights but license them freely subject to the condition that those who use, or improve, the software make it available on the same terms. For a collection of licenses approved by the Open Source Institute, see $<$ www.opensource.org/licenses/index.php > (visited June 28, 2002).

45 Yochai Benkler, Coase's Penguin, or Linux, and the Nature of the Firm, 112 YALE L.J. 369 (2002). Cf. Lior Strahilevitz, Social Norms from Close-Knit Groups to Loose-Knit Groups, 70 U.CHI.L.REv. 357 (2003) (discussing situations in which relative strangers interact cooperatively). $46 \quad$ For a discussion of the ways in which the open source model does and does not apply to biomedical research, see Arti K. Rai, "Open and Collaborative" Research: A New Model for Biomedicine (forthcoming in AEI-Brookings) 
Barriers to collective action are likely to be particularly high when wet lab research has high commercial value. In this context, the players involved - small biotechnology companies, large agribusiness and pharmaceutical companies, not to mention universities and federal funding agencies - have asymmetric motivations and interests. While firms that make profits from end product patents might be able to reach agreement on licensing basic inventions widely on a low or no-royalty basis, firms (and universities for that matter) that focus exclusively on upstream research might believe in licensing more selectively at a higher royalty. ${ }^{47}$ The bargaining difficulties created by asymmetric interests are only exacerbated when parties hold asymmetric rights - that is, if one party holds a broad foundational patent while other parties have narrower improvement patents. Compound these tactical asymmetries with informational deficits regarding valuation, and it is hardly surprising that we have not seen much movement towards collective rights management.

With respect to research of uncertain commercial value, the prospects for collective action should be higher. As an initial matter, for at least some of this research, the central players - primarily universities and other non-profit institutions - are more homogeneous. In addition, by definition, the likelihood of gain from strategic behavior is lower than in the context of high-margin research. Indeed, we have seen some evidence of collective self-restraint on the part of universities. For example, in the context of the Human Genome Project, academic scientists, working with the National Institutes of Health ("NIH"), achieved an approximation of university-level collective action by appealing to traditional scientific norms of open access: once the genome scientists had agreed not to seek proprietary rights in raw human genome sequence data, these scientists

47 Rai, Regulating Scientific Research, at 133 (making this point) 
also managed to convince their respective institutions to go along with their agreement (the so-called "Bermuda principles"). ${ }^{48}$

It is important to emphasize, however, that the collective action in this case was instigated by a tightly knit group of influential scientists who adhered to communal views of science, backed by the institutional weight of the National Institutes of Health ("NIH"), and more or less foisted on the scientists' respective universities. Without these preconditions, collective action at the university level may be difficult to achieve. The available empirical evidence indicates that, unlike the scientists who worked on the Human Genome Project, university technology transfer are often evaluated on the basis of, and motivated in significant part by, the desire to increase licensing revenue. ${ }^{49}$ Perhaps not surprisingly, then, agreements to secure collective action that have not been led by scientists have been less than successful. Consider the case of the Uniform Biological Materials Transfer Agreement ("UBMTA”). In this voluntary agreement, reached in 1995 between university technology transfer officers from more than 100 institutions, the officers committed themselves to making unpatented biological materials freely available within the academic sector for research purposes. Compliance with this standard form MTA does not appear to have been uniform: as noted earlier, an NIH working group found that, at least in the late 1990s, many transfers of research tools between universities contained onerous restrictions.

In the case of transfer of research tools between universities, however, we are dealing in most cases with research of uncertain rather than demonstrably low value. By

\footnotetext{
48 Eliot Marshall, Genome Researchers Take the Pledge: Data Sharing, SCIENCE, April 26, 1996, at 477.

49 Thursby, Jensen, \& Thursby (2001) (over 70\% of 62 technology transfer offices surveyed reported that their primary goal was licensing revenues).
} 
definition, this uncertainty means that some of the materials may ultimately yield some profit. Failure to include proprietary restrictions in an MTA means the loss of these potential profits. As a consequence, university technology transfer offices (“TTOs") who are highly averse to losing revenue opportunities may be reluctant to approve free distribution. Risk-aversion may be particular high for university technology transfer officers who are less sophisticated, are under pressure to increase licensing revenues, and/or have unrealistic expectations of profitability. ${ }^{50}$

Because of the distinction between research of uncertain and low value, the less than complete success of the UBMTA does not necessarily bode ill for efforts at university collective action in the humanitarian context. While universities and technology transfer officers may be uncomfortable about foregoing an uncertain, but potentially large, revenue stream, they should be less concerned about relinquishing monetary gains from licensing directed towards developing country research. In the latter case, the value of the revenue stream foregone is unequivocally quite modest. The possibility of significant reputational benefit at modest financial cost should also make collective action enticing for universities and other non-profit institutions.

\section{Public Sector Efforts at Collective Action}

Given this backdrop, it is not surprising that public sector institutions have launched significant efforts to manage proprietary rights in a manner that benefits the developing world. Roger N. Beachy, president of the Donald Danforth Plant Science Center in St. Louis, Missouri, recently authored an editorial in Science noting that, at his Center, all research and licensing agreements alert parties that the Center will preserve

$50 \quad$ Although university technology licensing operations are generally not profitable, a few universities such as Columbia and the University of California system, have garnered considerable revenue from such licensing. The example of these universities may be enticing to less profitable offices. 
the availability of intellectual property rights for meeting the needs of developing countries. ${ }^{51}$ Beachy argues that the experience of the Danforth Center over the past three years has been that private sector companies have been willing to accept such restrictions on licensing. He urges all academic and non-profit research institutions to include such terms in their licensing agreements. As he points out, "[a]lthough there may be a modest financial cost of taking such a position, the potential benefits in terms of regaining public trust, and ultimately of deploying technologies where they may be needed most, far outweigh the financial or opportunity costs."

Indeed, 21 non-profit institutions with heavy research agendas in agriculture, as well as the U.S. Department of Agriculture, have now joined together to heed Dr. Beachy's call. They have publicly committed themselves to articulating "best practices" that include the possibility of systematically retaining rights so as to allow public sector researchers freedom to operate in the context of developing-world-oriented research. ${ }^{52}$ The collective institutional framework within which these best practices will be articulated is the newly established Public-Sector Intellectual Property Resource for Agriculture ("PIPRA"). ${ }^{53}$ PIPRA will also be responsible for studying the possibility of pooling complementary technologies held by the public sector and making these technology "packages" available at a low royalty for agricultural research applications in the public sector and in developing countries. ${ }^{54}$ Finally, PIPRA will assist in developing

\footnotetext{
$51 \quad$ Roger Beachy, IP Policies and Serving the Public, 299 SCIENCE 473 (2003).

52 See www.pipra.org/activities.php; see also Atkinson et al., supra note 14, at 175 (statement by Presidents of 14 of these 22 institutions).

53 Some individual universities have already undertaken humanitarian licensing in particular contexts. For example, U.S. patent 5,859,339, granted to Regents of the University of California for a gene that enhances resistance to Xanthomonas, is now being made available to developing countries at zero royalty. Fischer et al., Collaborations in Rice, SCIENCE 290 (5490): 279.

$54 \quad$ www.pipra.org/activities.php
} 
a collective public sector IP asset database that will supplement existing efforts to inform researchers about freedom to operate obstacles. ${ }^{55}$

Proliferating proprietary rights have impeded developing country-oriented research not only into transgenic crops but also into new techniques of conventional breeding. ${ }^{56}$ One recent collective effort to address this problem involves a consortium of researchers at twelve institutions that is making publicly available molecular biology techniques that will assist in conventional breeding of wheat. The primary technique is "market assisted selection" or MAS. While conventional breeding has traditionally relied on visible traits to select improved varieties - a procedure that often requires waiting many generations - MAS looks for markers that are inherited along with the desired trait. MAS thus allows plants that carry the trait to be picked out quickly. The consortium website contains research protocols and marker sequences that researchers all over the world can freely access and use. ${ }^{57}$

Notably, collective action by universities and other non-profit institutions - even without the participation of the private sector - has the potential to be quite effective. In the area of agricultural technologies, the public sector owns $24 \%$ of plant biotechnology patents granted in the U.S. between 1982 and 2001. Many of these patents cover fundamental research tools that are essential for future research. ${ }^{58}$ Although some publicly-owned patents - such as methods for gene transfer - have unfortunately already been licensed exclusively to the private sector, licensing of enabling technologies on which the public sector is currently working, such as selectable markers, could be done

\footnotetext{
$55 \quad I d$.

Knight, supra note

Id.

See generally Graff et al. at 992-94 (discussing enabling technologies and trait technologies patented by the public sector).
} 
under the best practices articulated by PIPRA. Even with respect to patents that have already been licensed exclusively, public sector ownership could conceivably confer some leverage. At a minimum, useful collective efforts could be made towards making transparent the licensing status of technologies owned by the public sector.

In the biomedical arena, the public sector presence is also quite significant. In the genomics area, for example, $42 \%$ of patents are owned by either universities, nonprofit research institutes, or the U.S. government. ${ }^{59}$ Various efforts at public sector collective action for humanitarian purposes are also beginning to take shape. For example, the London-based Centre for the Management of Intellectual Property in Health Research and Development ("MIHR"), an organization set up in 2002 to improve access to health products in developing countries, has devoted significant energy to developing a best practices handbook on intellectual property management. ${ }^{60}$ Some of these best practices relate to licensing schemes that universities can use to ensure their technology transfer benefits developing countries. For example, Lita Nelsen, head of the MIT Office of Technology Transfer and MIHR advisor, suggests that universities might prohibit licensees from filing developing country patents on research tools that can be used without further development. ${ }^{61}$ Nelsen also suggests that, with respect to patents on end product drugs that have significant first world markets, universities might prohibit licensees from filing patents in developing countries. A newly formed coalition called Universities Allied for Essential Medicine (“UAEM”) has gone several steps further in terms of its suggestions for robust collective action to develop a public domain for

\footnotetext{
59 Stephen McCormack and Robert Cook-Deegan, DNA Patent Database (slide presentation on file with author)

60 MIHR Handbook of Best Practices for Management of Intellectual Property in Health Research and Development, available at www.mihr.org

$61 \quad$ MIHR Handbook at 77. Id. at 75-76.
} 
developing country research and drug distribution. Under the UAEM proposal, university research tool licenses would specifically preserve open access for entities that wanted to use the tools to do research on diseases that primarily afflict developing countries (and hence tend to be neglected by the commercial sector). Any entity that wanted to do so such research would simply notify the university of its intent. ${ }^{62}$ The UAEM approach would also require licensees to grant back any improvement patents so that these patents would be available for open use in neglected disease research.

To be sure, efforts in health-related biotechnology as not as advanced as in the agricultural sector: neither MIHR nor UAEM has thus far enlisted the public support of significant numbers of universities. Indeed, some have suggested that licensees might not sign on to a grant back approach of the sort suggested by UAEM. ${ }^{63}$ Nonetheless, more so than with high-commercial value research, or even research of uncertain commercial value, it should be possible to achieve some collective agreement. The success of one initiative in the AIDS vaccine arena, the International AIDS Vaccine Initiative ("IAVI"), suggests that some type of collective action might be possible. IAVI funds research and development on AIDS vaccine candidates for the developing world. Specifically, IAVI focuses on HIV-1 subtypes $\mathrm{C}$ and A, which are the major subtypes of HIV-1 prevalent in sub-Saharan Africa, India, and China. In contrast, HIV-1 subtype B , on which most vaccine research to date has focused, is prevalent in North America and Europe. Organizations that receive such funding (including, to date, Oxford University, the

\footnotetext{
62 UAEM Draft Developing Country License (on file with author). With respect to patents and related proprietary information on end product drugs, the UAEM draft indicates that university licensing should preserve open access for entities that want to manufacture the drug for use in developing countries. ${ }_{63}$ See MIHR Handbook at 76 (suggestion by Lita Nelsen that licenses might be unwilling to give universities power over improvement patents, particularly "if the university's invention, at the time it was licensed, is still far from a product.")
} 
Imperial College of Science and Technology, and the Aaron Diamond AIDS Research Center) must agree, as a condition of such funding, to make any vaccine that is developed available at a "reasonable price" in the developing world. ${ }^{64}$ Reasonable price includes actual costs of production, as well as a profit margin, but does not include R\&D. To the extent that a given organization does not succeed in developing and manufacturing a vaccine, it must give IAVI royalty-free rights to practice any patent it has in the area of vaccine research. ${ }^{65}$ That public sector organizations would agree to relinquish control over patent rights relevant to the developing world suggests that collective management of university rights in a manner helpful to the developing world is realistic.

\section{Limitations of Public Sector Collective Action}

Reliance on voluntary collective action by public sector institutions to address the needs of developing countries has limitations. As an initial matter, public sector institutions own only a portion of the relevant intellectual property. Even in the area of agricultural biotechnology, which has long been dominated by public sector research, only about one-quarter of patents are held by the public sector. In addition, critical public sector patents - such as the technology for inserting new genes into plants - are effectively owned by the private sector in that they have been licensed exclusively to private firms with no reservation of rights. Hence the role of the private sector merits discussion.

\section{A. The Role of the Private Sector}

\footnotetext{
64 The definition of reasonable price is based on a number of criteria, including the income level of the developing country. Developing countries are those that meet World Bank criteria for lower and middle income countries. IAVI currently has agreements with 6 Vaccine Development Partnerships and intends to be in Phase III trials on one candidate vaccine by 2004.

$65 \quad$ See IAVI Industrial Collaboration Agreement (on file with author).
} 
Where research and development involves proprietary rights held by private sector institutions, addressing the obstacles posed by such rights will be more difficult. Nonetheless, the public sector may be able to catalyze collective action across the publicprivate divide. As in the public sector (though perhaps not to the same extent), the modest revenue streams foregone, combined with positive reputational effects, should make collective action more likely. For example, transgenic B-carotene-enhanced rice (so-called "Golden Rice"), which could alleviate vitamin-A deficiency suffered by as many as 400 million individuals in the developing world, was created by Ingo Potrykus and his colleagues at the publicly-funded Swiss Federal Institute of Technology in Zurich. But producing this rice for the developing world involved overcoming the barriers posed more than 70 patented or proprietary methods and materials belonging to 32 different companies. After substantial effort by the public sector, including significant personal negotiation by Ingo Potrykus himself, agreements were reached that allowed public sector scientists to proceed with research to develop lines of golden rice without paying licensing fees. In particular, Potrykus and his public sector allies were able to persuade a number of major companies, including Monsanto, Sygenta, and Bayer, to donate their proprietary technologies for production of B-carotene-enhanced rice in the developing world. ${ }^{66}$

With respect to research focused on developing country diseases, IAVI has had some success in enlisting the private sector on the same terms as it has enlisted the public sector. Currently, it has three private sector collaborators. More generally, the development of therapies to treat developing country diseases will likely be assisted by

66 Monsanto has also put its rice genome in public domain, so as to allow public International Rice Genome Sequencing Project (IRGSP) to finish the task more quickly and at lower cost. 
access to small molecule chemical libraries. ${ }^{67}$ These libraries are generally held as trade secrets by pharmaceutical companies. If pharmaceutical companies could be assured that use of their libraries would be restricted to developing country diseases, they might be willing to donate their libraries for research on those diseases. Even where public sector action does not catalyze donation of proprietary technologies for the developing world, it might help to produce intellectual property clearinghouses where rights to such technology would be available at relatively low cost. ${ }^{68}$

\section{B . Obstacles Unrelated to Intellectual Property}

Another important set of objections to reliance on voluntary collective action revolves around the reality that intellectual property rights represent only a part of the problem in terms of generating R\&D oriented towards the developing world. Perhaps most obviously, once upstream intellectual property hurdles are overcome, public sector funding will be necessary to pay for the large capital and labor costs of research and development. ${ }^{69}$ These R\&D costs are likely to be particularly high in the area of biomedical research. For example, although IAVI has cash reserves of approximately $\$ 250$ million, this is only about half of the sum the organization says it needs to execute its plans. ${ }^{70}$ In contrast, in the year 2000, the pharmaceutical company Merck devoted

67 Small molecule drugs, which can usually be taken orally, work to "knock out" molecules (socalled "targets") that are implicated in the onset or progression of a given disease.

68 Geoffrey Graff and David Zilberman, An Intellectual Property Clearinghouse for Agricultural Biotechnology, 19 NATURE BIOTECHNOLOGY 1179 (2001).

69 In many cases, the technical difficulty of the task is also considerable. For example, in the case of a potential AIDS vaccine for the developed world, efforts have been ongoing since the late 1980s. Yet the candidate vaccines have yielded little in the way of clinical success. Developers of products for developing countries, particularly in the biomedical arena, may also face considerable hurdles in terms of getting regulatory approval. For example, approval for conducting phase III efficacy trials in the developing world can be difficult to obtain.

70 Laurie Garrett, Back To Basics: AIDS at 20, NEWSDAY, June 5, 2001. As various commentators have noted, public sector funding could operate as either a "push" or "pull" mechanism. Under a push mechanism, such as that employed by IAVI, the public sector funds the research directly. Under a pull mechanism, the public sector might guarantee a paying market for a particular vaccine or therapy. 
$\$ 2.4$ billion to developing an AIDS vaccine for the developed world. ${ }^{71}$ Nonetheless, even if upstream proprietary rights represent only a small portion of the problem with respect to producing biotechnological products for the developing world, collective action can and should work to ensure that such rights do not pose an obstacle.

\section{Conclusion}

Private sector collective action that facilitates free rights exchange is often proposed as an efficient solution to difficulties created by increasing proprietary complexity in the research arena. This paper has argued that, at least in the area of biotechnology, we have not seen such activity, and we should not be surprised by its absence. What we should expect, and what has in fact arisen, is public sector collective action in research areas of low commercial value. Although such public sector collective action has many limitations, it is a valuable first step towards generating research that addresses the health problems and food security needs of developing countries.

$71 \quad$ Id. 